\title{
ZANIKAJĄCA SPOŁECZNOŚĆ. KATOLICKI KOŚCIÓŁ CHALDEJSKI W IRANIE PO REWOLUCJI IRAŃSKIEJ 1979 ROKU
}

DOI: http://dx.doi.org/10.12775/TiCz.2017.056

Badania najnowszej historii chrześcijan w Iranie, ich aktywności po rewolucji irańskiej 1979 roku $^{* *}$ oraz sposobów postrzegania i kategoryzowania kraju, w którym mieszkają, napotykają szereg trudności. Jedną z nich jest zmieniający się charakter chrześcijaństwa w Islamskiej Republice Iranu, wywołany z jednej strony migracjami członków Kościołów tradycyjnych ${ }^{1}$, z drugiej zaś pojawieniem się i wzrostem - pomimo

* Dr Marcin Rzepka, adiunkt w Instytucie Historii Uniwersytetu Papieskiego Jana Pawła II w Krakowie, zajmuje się historią misji chrześcijańskich oraz chrześcijaństwa na Bliskim Wschodzie (marcin.rzepka@upjp2.edu.pl).

** Artykuł powstał w ramach projektu finansowanego przez Narodowe Centrum Nauki na podstawie umowy UMO-2013/11/B/HS1/03962.

1 Za tradycyjne w Iranie uznaje kościoły istniejące na terytorium tego kraju przed pojawianiem się misjonarzy katolickich czy protestanckich, jak również Katolickie Kościoły Wschodnie, a zatem: Ormiański Kościół Apostolski, Ormiański Kościół Katolicki, Asyryjski Kościół Wschodu, Chaldejski Kościół Katolicki. Szerzej na temat zmian demograficznych wśród mniejszości religijnych w Iranie: C. V. Prorok, M. Hemmasi, Demographic Changes in Iran's Officially Recognized Religious Minority Populations Since the Islamic Revolution, „African and Asian Studies” 1 (2002) 2, s. 63-86; J. Barry, 'This is 
prześladowań ze strony państwa - wspólnot chrześcijańskich skupiających Irańczyków, konwertytów na chrześcijaństwo ${ }^{2}$. Sytuacja polityczna w kraju będącym republiką muzułmańską (dżomhuri-je eslāmiª uniemożliwia praktycznie badania tej ostatniej grupy, ogranicza też możliwości ich prowadzenia wśród „oficjalnych mniejszości” (aqalijat-e rasmi) ${ }^{4}$, do których należą chrześcijanie - Asyryjczycy i Ormianie. Otrzymali oni wprawdzie po rewolucji gwarancje konstytucyjne ${ }^{5}$, jednak ich pełna partycypacja w przemianach społecznych, kulturalnych i politycznych kraju jest ograniczona. Posiadają miejsca kultu, prowadzą szkoły, wydają publikacje i w granicach wyznaczonych przez władze Iranu rozwijają działalność społeczno-kulturalną, tworząc instytucje religijne i świeckie. Jednym z możliwych ujęć historii chrześcijan może być zatem historia instytucjonalna, historia instytucji, w tym kościołów, szkół i stowarzyszeń.

Spadek liczby wiernych Kościołów tradycyjnych oraz pojawienie się nowych chrześcijan, identyfikowanych przez odwołanie do języka perskiego - perskojęzycznych chrześcijan (masihijān-e färsi zabān) wpływa na charakter materiału dokumentującego działalność Kościołów i wspólnot chrześcijańskich w Iranie, ukazując prymat relacji ustnych nad materiała-

not Our Country': Declining Diversity in the Islamic Republic of Iran, „The Muslim World” 105 (2015) 3, s. 281-298.

${ }^{2}$ Problematyka konwertytów w Iranie doczekała się już stosunkowo licznych opracowań, analiz, raportów: M. Bradley, Too Many to Jail. The Story of Iran's New Christians, Oxford - Grand Rapids 2014; M. Rzepka, New Christians in the Islamic Republic of Iran: Regional and Global Implication, Shifting Identities: Changes in the Social, Political, and Religious Structures in the Middle East, red. M. Raheb, Diyar Publisher 2016, s. 183--194.

${ }^{3}$ Przy zapisie wyrazów perskich przyjęto zasadą maksymalnego ich spolszczenia, wprowadzając jednak rozróżnienie między samogłoskami $a$ i $\bar{a}$, spółgłoski $\dot{\varepsilon}$ oraz oddawane są literą $q$.

${ }^{4}$ Badania wśród chrześcijan w Iranie, zważywszy na konsekwencje, jakie mogą mieć one dla badanej grupy, wymagają zachowania prawa do anonimowości rozmówców. W trakcie badań przeprowadzonych w Iranie w listopadzie 2015 oraz sierpniu 2016 roku przeprowadzono 12 wywiadów z przedstawicielami Kościołów chaldejskiego i rzymskokatolickiego. Wywiady prowadzone były w języku perskim. Na potrzeby artykułu przywołuję wypowiedzi zaledwie dwóch osób: [1_M.A.] - świecki pracownik Kościoła chaldejskiego, lat 50, od 30 lat w Teheranie, rozmowa przeprowadzona w Teheranie 5.11.2015; [2_J.K.] ksiądz (ryt łaciński), Asyryjczyk, lat 45, rozmowa przeprowadzona w Teheranie 7.11.2015.

${ }^{5}$ E. Sanasarian, Religious Minorities in Iran, Cambridge 2000, s. 64-72. 
mi archiwalnymi ${ }^{6}$. Dodatkowo podejmowane przez Kościoły inicjatywy na rzecz dokumentacji własnej historii każą uwzględnić w analizach fenomen nowych mediów, które stopniowo przekształcają się w „cyfrowe archiwa”, gromadząc zdjęcia, raporty oraz świadectwa i relacje chrześcijan. Dotyczy to $\mathrm{w}$ zasadzie wszystkich grup chrześcijańskich w Iranie ${ }^{7}$. Pogłębiona refleksja reprezentantów różnych Kościołów w Iranie nad stanem chrześcijaństwa w tym kraju przy jednoczesnym usilnym dokumentowaniu własnej historii zdaje się odzwierciedlać bardzo trudną sytuację, w jakiej się znaleźli w wyniku przemian społeczno-politycznych wywołanych rewolucją, która znacząco wpłynęła na zintensyfikowanie procesów migracyjnych po 1979 roku.

Trudności w badaniu najnowszej historii Kościoła Chaldejskiego w Iranie odpowiadają zarysowanym powyżej zagadnieniom. Dodatkowo jednak tego typu studia wymagają uwzględnienia kategorii tożsamości oraz problemu autoidentyfikacji członków Kościoła. Deklarowana przez nich tożsamości asyryjska ${ }^{8}$, dzielona z wyznawcami Asyryjskiego Kościoła Wschodu oraz Asyryjczykami - protestantami, nierzadko wpływa na pomijanie różnic konfesyjnych $\mathrm{w}$ analizach ${ }^{9}$. Wynika to $\mathrm{z}$ pewnością z regulacji prawnych i irańskiej konstytucji, która przewiduje dla społeczności asyryjskiej, bez względu na przynależność wyznaniową, jedno miejsce w irańskim parlamencie (madżles). Podobnie instytucje, zadaniem których jest reprezentowanie Asyryjczyków w państwie, mają charakter jednoczący. Przykładem takiej organizacji, bodaj najważniejszej w dzisiejszym Iranie, jest Stowarzyszenie Asyryjczyków w Teheranie (Andżoman-e

${ }^{6} \mathrm{~W}$ istocie w związku $\mathrm{z}$ aktami wandalizmu w trakcie rewolucji, a także w okresie porewolucyjnym, gdy niektóre biblioteki przykościelne zostały zamknięte, a materiały $\mathrm{w}$ nich przechowywane skonfiskowane, jednym z możliwych badań pozostają rozmowy ze świadkami historii.

7 Por. raport przygotowany przez organizację Small Media z siedzibą w Londynie: Heretics. Iran's Religious Minorities, Small Media 2014, https://smallmedia.org.uk/work/ heretics-irans-religious-minorities [dostęp: 10.06.2017].

${ }^{8}$ Problematyka ta sama w sobie wydaje się bardzo złożona, o czym przekonuje praca: M. Woźniak, Wspótcześni Asyryjczycy i Aramejczycy. Bliskowschodni chrześcijanie w poszukiwaniu tożsamości narodowej, Łódź 2014.

9 Wydaje się, że jest to dominujący sposób prezentacji, często jednak eksponuje się tylko Asyryjski Kościół Wschodu, por. Ettelāāti czand dar bāre-je Āszurihā, Markaz-e pażuheszhā-je Dżomhuri-je Eslāmi 1377 (=1998). 
Āszurihā- je Tehrān). Wydaje ono dwujęzyczne pismo (w języku perskim i neoaramejskim) „Pajām-e Aszurijān”. Tożsamość i autoidentyfikacja ukazują w jakimś sensie pozainstytucjonalną historią Kościołów tradycji wschodniosyryjskiej w Iranie (czyli właśnie Kościoła Chaldejskiego oraz Asyryjskiego Kościoła Wschodu). Wydaje się, że rewolucja - na elementarnym poziomie, zważywszy na niewielką społeczność Asyryjczyków przyczyniła się do wytworzenia nowych sieci komunikacji i współpracy wśród wiernych, którzy spotykają się na nabożeństwach w różnych Kościołach. Asyryjczycy dodatkowo, w przeciwieństwie do Ormian w Iranie, tworzą grupę znacznie bardziej otwartą na wpływy kulturowe; odnosi się to przede wszystkim do wykorzystanie języka perskiego w kontekście religii. Uwzględniając zatem problematykę tożsamości chrześcijan oraz podejmowaną przez nich refleksję nad historią Kościoła i własnej społeczności, można zaobserwować dwa typy narracji bazujących na odmiennych odniesieniach czasowych oraz przestrzennych. Pierwsza z nich to opowieść tworzona przez księży oraz pracowników Kościołów, którzy uwzględniają całościowy i instytucjonalny wymiar irańskiego chrześcijaństwa. Druga zaś to historia tworzona przez wiernych, dla których punktem odniesienia jest symboliczna geografia Kościoła i poczucie straty wywołanej rewolucją. Przejawia się to, między innymi, w przywoływaniu w rozmowach nazw ulic, dzielnic czy nawet niektórych miast, które były w użyciu w okresie poprzedzającym rewolucję, i w stałym kontrastowaniu obecnej rzeczywistości z czasem przedrewolucyjnym. To historia emocjonalna, osobista, a tworzący ją wierni zdecydowanie częściej wypowiadają się krytycznie na temat Iranu oraz islamu.

Uwzględniając zatem złożoność problematyki związanej z chrześcijaństwem w dzisiejszym Iranie, artykuł stawia sobie za cel przedstawienie zmian, jakie zaszły w społeczności wiernych Kościoła Chaldejskiego w Iranie od czasów rewolucji irańskiej w 1979 roku przez zaakcentowanie zmian o charakterze ilościowym, które oczywiście przekładają się na zmiany jakościowe. Trudno jednak zrozumieć obecną sytuację bez określenia stopnia rozwoju społeczno-kulturalnego Asyryjczyków przed rewolucją, a tym samym również sentymentu, jakim darzą ten okres wierni omawianego Kościoła. 


\section{KOŚCIÓł CHALDEJSKI W IRANIE PRZED 1979 ROKIEM}

W historii Kościoła Chaldejskiego w XX wieku ${ }^{10}$ możemy wyróżnić kilka kluczowych momentów decydujących o jego dystrybucji geograficznej i wpływających na jego strukturę administracyjną w Iranie. Będzie to przede wszystkim I wojna światowa, która doprowadziła do niemal całkowitego odpływu chrześcijan z terenów północno-zachodniego Iranu, dzisiejszej wschodniej Turcji i ich rozmieszczenia w Iraku. Faktycznie w okresie powojennym (po 1918 roku) Irak stał się krajem, w którym wierni Kościoła Chaldejskiego stanowili większość na tle innych grup chrześcijan. Wykazywali oni również silne tendencje asymilacyjne, w większym stopniu używając języka arabskiego ${ }^{11}$. W samym zaś Iranie I wojna światowa zapoczątkowała migracje chrześcijan z terenów przylegających wówczas do imperium osmańskiego ${ }^{12}$, opuszczanie przez nich miast Salmas oraz Urmii i stopniowe osiedlanie się w stolicy kraju - Teheranie. W roku 1925 przebywający w Teheranie Asyryjczycy podjęli działania na rzecz powrotu do Iranu współwyznawców, którzy w czasie wojny schronili się w obozie w miejscowości Bakuba, na północ od Bagdadu, jednak $\mathrm{z}$ niewielkim skutkiem.

W okresie II wojny światowej nasiliły się migracje z obszarów północno-zachodniego Iranu, zwłaszcza z prowincji Azerbejdżan i Kurdystan, przyczyniając się tym samym do znacznego wzrostu populacji w Teheranie. W latach sześćdziesiątych i siedemdziesiątych XX wieku, na fali urbanizacji oraz uprzemysłowienia, notujemy natomiast wzrost migracji na południe kraju do Ahwazu, centrum irańskiego przemysłu naftowego

${ }^{10}$ Doskonałą prezentację historii Asyryjskiego Kościoła Wschodu oraz Kościoła chaldejskiego przynosi praca: D. Wilmshurst, The Ecclesiastical Organisation of the Church of the East 1318-1913, Louvain 2000, zdecydowanie jednak większość opracowań koncentruje się na Kościele Wschodu: D. Wilmshurst, The Martyred Church. A history of the Church of the East, London 2011.

${ }^{11}$ J. Healey, 'The church across the border': The Church of East and its Chaldean branch, w: Easter Christianity in the Modern Middle East, red. A. O’Mahony, Emma Loosley, London - New York, 2010, s. 46.

12 Również polska prasa katolicka informowała o losie chrześcijan w tym regionie, por. Persya. Rzut oka na dzieje misyi. Wymordowanie 4000 chrześcijan i arcybiskupa Sontaga w Urmii, „Misye katolickie”, r. 38 (styczeń-luty), 1919, s. 58-59. 
oraz Teheranu. Typowa dla wyznawców Kościoła Chaldejskiego oraz Asyryjskiego Kościoła Wschodu była wówczas zmiana charakteru populacji na bardziej miejski. Odpowiadało to również ogólniejszym procesom rozwojowym zachodzącym w Iranie, na które nakładał się również wzrost liczby ludności w kraju. W przypadku wiernych Kościoła Chaldejskiego, a ogólnie w odniesieniu do Asyryjczyków w Iranie oznaczało to spadek znaczenia dawnych centrów kulturowych znajdujących się w okolicach jeziora Urmia, w miejscowości Salmas czy Tebrizie, na rzecz nowych, powstających w rozwijającej się dynamicznie stolicy kraju.

$\mathrm{Na}$ początku XX wieku chrześcijanie (w tym Ormianie tworzący do dzisiaj najliczniejszą grupę) stanowili około 1\% liczącej około 10 milionów populacji Iranu. Przed wybuchem rewolucji w 1978 roku, gdy liczba ludności przekroczyła 33 miliony, populacja chrześcijan wynosiła 280 tysięcy, z czego zaledwie 30 tysięcy należało do Kościoła Chaldejskiego. Stanowili oni jednak większość wśród wszystkich chrześcijan deklarujących się jako Asyryjczycy, których całkowita liczba wynosiła 58 tysięcy ${ }^{13}$. Zdecydowana większość $\mathrm{z}$ nich mieszkała wówczas w stolicy kraju. Tabela 1 ukazuje zmiany zachodzące $\mathrm{w}$ okresie poprzedzającym rewolucję. Przy zwiększającej się liczbie ludności kraju centra, jakim dla chrześcijan tradycji wschodniosyryjskiej (z Kościoła Wschodu oraz Kościoła Chaldejskiego) była wspomniana już Urmia oraz Salmas, straciły na znaczeniu w wyniku silnych migracji wewnętrznych. Teheran stał się absolutnym centrum religijnym oraz kulturowym zamieszkujących Iran Asyryjczyków.

Tabela 1. Liczebność wiernych Kościoła Chaldejskiego w Iranie przed 1979 rokiem

\begin{tabular}{|l|c|c|}
\hline & $\mathbf{1 9 3 7}$ & $\mathbf{1 9 7 8}$ \\
\hline Urmia & 6000 & $\mathbf{7 0 0 0}$ \\
\hline Salmas & 3350 & \\
\hline Sehna (Sanadadż) & 1932 & 4000 \\
\hline Teheran & & 15000 \\
\hline
\end{tabular}

${ }^{13}$ G. Yonan, Assyrer heute: Kultur, Sprache, Nationalbewegung der aramäisch sprechenden Christen im Nahen Osten; Verfolgung und Exil,: Sprache, National- beverung der aramdisch sprechenden Christen in Nahen Osten, Verfolgung und Exil, Wien-- Hamburg 1978, s. 92. 
Tabela 1. cd.

\begin{tabular}{|l|c|c|}
\hline & $\mathbf{1 9 3 7}$ & $\mathbf{1 9 7 8}$ \\
\hline Chuzestan & & 2000 \\
\hline Kermanszah i Hamadan & & 2000 \\
\hline Liczba całkowita & 11282 & 30000 \\
\hline
\end{tabular}

Źródło: D. Wilmshurst, The Martyred Church, s. 445; G. Yonan, Assyrer heute, s. 92.

Zmiany demograficzne oraz depopulacja historycznych centrów wymusiły konieczność utworzenia nowych jednostek administracyjnych Kościoła. Patriarcha Kościoła rezydował w Bagdadzie, strukturalnie zaś Kościół podzielony był na cztery archidiecezje: w Kirkuku, Sanandadżu (Sehna), Urmii-Salmas, Basrze. Działało sześć diecezji: w Al-Amadiji, Akrze, Mardin, Mosulu, diecezja Syrii i Libanu oraz w Zakho. W styczniu 1966 została utworzona archidiecezja w Ahwazie, gdzie znaczna liczba Asyryjczyków znalazła zatrudnienie w przemyśle naftowym. W 1971 archidiecezja w Sanandadżu została przeniesiona do Teheranu. Odzwierciedlało to faktyczny stan liczebny wiernych i odpowiadało działaniom podjętym przez arcybiskupa Josepha Szeicho (Cheikho), który przeniósł swoją siedzibę do Teheranu już w 1944 roku. W tym też czasie wzrastała populacja Chaldejczyków w Teheranie ${ }^{14}$. Sprzyjało to podejmowaniu inicjatyw o charakterze instytucjonalnym. Część z nich miała zdecydowanie charakter religijny, przewodził im arcybiskup, część zaś świecki podejmowany przez asyryjskich działaczy społecznych, kulturalnych oraz polityków.

W odniesieniu do Kościoła Chaldejskiego w Teheranie najważniejszym wydarzeniem - również o charakterze symbolicznym - była rozpoczęta w 1945 roku budowa kościoła św. Józefa ${ }^{15}$, który faktycznie w późniejszych latach stał się centrum kształtującym tożsamość religijną i kulturową wiernych. Projekt kościoła przygotował architekt asyryjski David Uszan (1929-2014). Przy kościele powstała szkoła „Behnam”. Nieco później, w 1954 roku, powstała kolejna chaldejska szkoła w Teheranie „Hazrat-e Marjam”.

${ }^{14}$ D. Wilmshurst, The Martyred Church, s. 446.

15 W. Bajt-Mansur, Namunehā-ji az āsār-e bāstāni-je Āszurihā-je Irān, Tehrān 1377 (=1998), poz. 31 . 
Okres panowania Pahlawich, zwłaszcza zaś Mohammada Rezy Pahlawiego (1941-1979) gwarantował Asyryjczykom rozwój społeczny, ekonomiczny i polityczny oraz wolność, jakiej nie doświadczali w żadnym innym kraju na Bliskim Wschodzie ${ }^{16}$. Okres ten przyczynił się do powstania i rozwoju organizacji asyryjskich. Bodaj najbardziej wpływowa była utworzona w sierpniu 1969 roku Federacja Asyryjczyków w Iranie powstała na wzór działającej od 1933 roku amerykańskiej American Assyrian National Federation. Jej działania wspierał wpływowy polityk asyryjski tego okresu Wilson Bajt-Mansur, parlamentarzysta w latach 1969-1975 oraz redaktor pisma „Atur”, ukazującego się do 1975 roku $^{17}$. Wilson Bajt-Mansur był drugim asyryjskim parlamentarzystą w okresie powojennym. Prawo do posiadania reprezentantów w parlamencie irańskim dawała mniejszościom (chrześcijanom - Ormianom i Asyryjczykom, zaratusztrianom oraz żydom) konstytucja uchwalona w roku $1907^{18}$. W okresie międzywojennym Asyryjczycy nie posiadali jednak swojego przedstawiciela, ich interesy reprezentowali Ormianie. Dopiero w 1959 roku na czteroletnią kadencję został wybrany William Ebrāhimi ${ }^{19}$. Ostatnim z przedstawicieli Asyryjczyków w parlamencie irańskim przed rewolucją był Homer Āszurijān.

Warto również wspomnieć o kontaktach międzynarodowych. W dniach 23-26 października 1971 roku odbył się w Teheranie kongres międzynarodowej organizacji skupiającej Asyryjczyków w świecie - Assyrian Universal Alliance (pers. Andżāman-e Āszurihā-je dżahān) ${ }^{20}$. Kontakty te kształtowały niewątpliwie tożsamość irańskich Asyryjczyków,

${ }^{16}$ R. Macuch, Assyrians in Iran, i. The Assyrian community (Āšūrīān) in Iran,. Encyclopaedia Iranica, II/8, s. 821, dostępne również on-line, http://www.iranicaonline. org/articles/assyrians-in-iran-i-communit [dostęp: 10.06.2017].

17 R. Macuch, Assyrians in Iran, s. 821.

18 Trudno przecenić znaczenie tej pierwszej irańskiej konstytucji w historii Iranu. Okres przełomu XIX/XX wieku ma przy tym bardzo istotne znaczenie dla rozwoju, kształtowania się i manifestowania świadomości narodowej Asyryjczyków w Iranie, por. A.H. Backer, Revival and awakening. American evangelical missionaries in Iran and the origins of Assyrian nationalism, Chicago-London 2015, s. 288-295.

19 R. Macuch, Assyrians in Iran, s. 820.

20 Por. informacje na stronie Assyrian Universal Alliance, http://aua.net/2014/10/ the-4th-congress-tehran-iran-october-23-26-1971/ [dostęp: 10.06.2017]. 
przejawiającą się w działalności naukowej oraz kulturalnej. Bardzo silne poczucie dziedzictwa starożytnej Asyrii korespondowało z programową „rewitalizacją" dawnych tradycji Iranu w przestrzeni politycznej i publicznej dokonywanych przez irańskiego monarchę. Wydaje się zatem, że porozumienie pomiędzy Asyryjczykami, mniejszością a państwem, które uosabiał w tym czasie szach - Mohammad Reza Pahlawi, zasadzało się na silnym przywiązaniu do przedmuzułmańskiego dziedzictwa kulturowego Iranu i cywilizacji rozwijających się na jego terenie. Warto wspomnieć, że w 1971 roku szach Iranu zorganizował obchody 2500-lecia istnienia monarchii perskiej, w której uczestniczyli również przedstawiciele irańskich mniejszości.

W okresie poprzedzającym rewolucję społeczność Asyryjczyków w Iranie, podzielonych wyznaniowo na Asyryjski Kościół Wschodu, Kościół Chaldejski oraz protestantów, z których najliczniejszy był Kościół ewangeliczny (prezbiteriański), rozwijała się, korzystając z sieci powiązań międzynarodowych. Podkreślanie wspólnej tożsamości asyryjskiej nie usuwało bynajmniej sporów i tarć w obrębie tych społeczności. Jednak to właśnie nawiązania do tradycji i dawnej historii zdają się cechować Asyryjczyków bez względu na ich przynależność wyznaniową. Pira Sarmas w swojej pracy wydanej w języku perskim w 1966 w Teheranie Hoquq-e baszar wa Āszurihā-je Irāni („Prawa człowieka i irańscy Asyryjczycy”) dokonał przeglądu historii Iranu w powiązaniu z Asyryjczykami, podkreślając ich rolę, znaczenie i zaangażowanie reprezentowanej przez siebie społeczności na rzecz rozwoju kraju. Samuel David Pirā w tworzonej przez siebie „asyryjskiej encyklopedii” (Dajerat-ol-māaref-e āszur) wskazywał czytelnikom te elementy, które składają się na „asyryjskość” Āncze hame-je Āszurijān bājad bedānand („To, co wszyscy Asyryjczycy muszą wiedzieć”) - historię, symbole narodowe, kościoły. Wspomniane tutaj prace w języku perskim nie oznaczają oczywiście braku zainteresowań własnym językiem. W tym czasie faktycznie rozwija się też literatura w języku neoaramejskim, powstają przekłady na ten język, rozwija się kaligrafia, której niedościgłym mistrzem pozostaje Issa Benyamin. Działanie na rzecz języka i kultury charakteryzuje również przedstawicieli Kościoła Chaldejskiego. Wielce zasłużony jest arcybiskup Issaji, który opracował szereg tekstów religijnych należących do tradycji wschodniosyryjskiej. Warto tu również przywołać chaldejski Instytut św. Jana (Kānun-e Juhannā-je rasul) założony w Tehe- 
ranie przez francuskiego księdza Pierre’a Humblota ${ }^{21}$. Instytut podejmował jednak prace na rzecz popularyzacji syryjskiej tradycji patrystycznej w języku perskim.

Okres przed rewolucją cechuje zatem rozwój instytucjonalny (kościoły, szkoły, organizacje), kulturalny (literatura, tłumaczenia, prasa) wsparty aktywnością międzynarodową Asyryjczyków. Nietrudno zatem zrozumieć, że ci, którzy pozostali w Iranie po rewolucji, wspominają go jako czas szczęścia, odnosząc się przy tym negatywnie do samej rewolucji. Jakie zatem zamiany przyniosła Asyryjczykom rewolucja islamska w Iranie? Jak wpłynęła na Kościół Chaldejski, posiadający w Iranie trzy diecezje: $\mathrm{w}$ Teheranie, Urmii-Salmas oraz w Ahwazie, którym kierowali rezydujący w Urmii arcybiskup Samuel Szauriz i przebywający w Teheranie arcybiskup Juhanna Issaji?

\section{KOŚCIÓł CHALDEJSKI I REWOLUCJA IRAŃSKA}

Bez wątpienia rewolucja irańska pozostaje najważniejszym wydarzeniem w najnowszej historii Iranu, determinując podejście Irańczyków do chrześcijaństwa i jednocześnie wymuszając na irańskich chrześcijanach konieczność określania własnej pozycji w rzeczywistości wykreowanej przez rewolucyjne interpretacje islamu. W czasie rewolucji oraz w pierwszych latach istnienia Islamskiej Republiki Iranu można dostrzec w działaniach chrześcijan próby wypracowania, czy może raczej wynegocjowania, odpowiednich relacji między państwem a Kościołami. Jednym z przykładów może być dyskusja nad projektem nowej konstytucji przyjętej przez irański parlament w grudniu 1979 roku. Faktycznie w odniesieniu do mniejszości religijnych został przyjęty model wypracowany jeszcze w pierwszej konstytucji z 1907 roku: „uznane mniejszości”, czyli żydzi, zaratusztrianie oraz chrześcijanie (ale tylko Ormianie i Asyryjczycy), miały prawo do posiadania swoich reprezentantów w parlamencie. Eliz Sanasarian, analizując stosunek państwa do mniejszości w okresie od rewolucji do śmierci ajatollaha Chomejniego w 1989 roku, zwraca uwagę na spory dotyczące zapisów konstytucyjnych, stanowiących o ich

${ }^{21}$ M. Bradley, Too many to jail, s. 179. 
prawach. Artykuł 64 Konstytucji Islamskiej Republiki Iranu określający liczbę reprezentantów poszczególnych mniejszości w madżlesie (jeden przedstawiciel społeczności żydowskiej, jeden zaratusztrianskiej, dwóch Ormian, jeden Asyryjczyk) został oprotestowany przez Bajt-Urszanę, asyryjskiego deputowanego, który zwracając uwagę na całkowitą liczbę Asyryjczyków - wliczając również przebywających poza granicami kraju - podkreślał konieczność podniesienia limitu z jednego do dwóch deputowanych, reprezentujących odpowiednio Kościół Wschodu oraz Kościół Chaldejski ${ }^{22}$. Uwag tych jednak nie uwzględniono. Oznaczało to $\mathrm{w}$ istocie konieczność podejmowania wspólnych inicjatyw przez reprezentantów wspomnianych Kościołów.

Nowe regulacje przyjęte przez irański rząd związane z prowadzeniem szkól, wydawanie publikacji, a także forsowane zmiany społeczno-kulturowe, jak obowiązek noszenia muzułmańskiej chusty (hedżāb-e eslāmi) przez kobiety, również chrześcijanki, wpływały niewątpliwie na poczucie alienacji chrześcijan, powodując falę migracji, wzmocnioną jeszcze wojną iracko-irańską. W tej nowej sytuacji Asyryjczycy próbowali przeorganizować instytucje działające przed rewolucją, inicjowali również nowe projekty. Jednym z nich było wydawanie pisma „Isztar”, w które zaangażował się Bajt-Urszana ${ }^{23}$, czy założenie w 1981 roku przez Wilsona Bajt-Mansura Centrum Narodowego i Kulturalnego Młodzieży Asyryjskiej (Kānun-e melli wa farhangi-je dżawānān-e āszuri), które nadawało między innymi audycje radiowe dla dzieci w języku neoaramejskim.

Zmiany $\mathrm{w}$ prawie prasowym oraz konieczność przedstawiania publikowanych materiałów do oceny irańskim cenzorom w tłumaczeniu na język perski wpływały na spadek publikacji w języku neoaramejskim, a przy tym - co zważywszy na działania władz irańskich w późniejszym czasie zmierzających do ograniczenia publikacji chrześcijańskich w języku perskim, wydaje się bardzo znamienne - wzrost perskojęzycznych publikacji. Homer Āszurijān, poseł asyryjski w ostatnim przedrewolucyjnym parlamencie, który opuścił Iran, udając się do USA, dowodzi, że zmiana sposobów zarządzania szkołami, na czele których stanęli muzułmanie,

22 E. Sanasarian, Religious Minorities, s. 69.

${ }^{23}$ Szerzej: E. Naby, The Assyrians of Iran: Reunification of a Millat 1906-1914, „International Journal of Middle East Studies” 8 (1977) 2, s. 237-249. 
a nie chrześcijanie, konieczność wprowadzenia odrębnych klas dla dziewcząt i chłopców, oraz inne ograniczenia nałożone na chrześcijan wpłynęły na ich postawy oraz decyzje o wyjeździe z kraju ${ }^{24}$. Wydaje się, że wspomniane trudności przyczyniły się do działań zmierzających do konsolidacji społeczności wierzących, wzmocnienia więzi kościelnych. Arcybiskup Issaji, nie krytykując bynajmniej bezpośrednio sytuacji w Iranie, stwierdzał $\mathrm{w}$ artykule zatytułowanym Tadżrobe āmuzande ast („Doświadczenie przynosi naukę”), że: „rewolucja islamska, kładąc nacisk na edukację religijną wyrwała nas ze snu"25. Artykuł, który ukazał się w 1982 roku w piśmie „Marga”, wskazywał na konieczność edukacji religijnej wśród chrześcijan, pośrednio zaś nawiązywał do sytuacji w Iranie i trwającej wówczas rewolucji kulturalnej (enqelāb-e farhangi), której nadrzędnym celem było dostosowanie uniwersytetów i szkół do wartości muzułmańskich.

Wydawane przez Asyryjczyków czasopisma, jak „Isztar”, silnie kształtowały postawy i opinie. Podobnie wydawane od 1979 roku przez Kościół Chaldejski, wspomniane powyżej pismo „Marga”, którego redaktorem naczelnym był arcybiskup Issaji, kształtowało ponadlokalną wspólnotę religijną, ukazując nie tylko problemy wewnętrzne społeczności, ale też zróżnicowanie katolicyzmu w świecie. Tym samym łączyło ono niewielką irańską społeczność wiernych Kościoła Chaldejskiego z globalnym katolicyzmem. W czasie rewolucji ulegał zatem wzmocnieniu aspekt religijny kontaktów międzynarodowych utrzymywanych przez Asyryjczyków. Podobnie również problemy chrześcijan w Iranie wzbudzały zainteresowanie światowej opinii publicznej. Gabriell Yonan w swojej pracy Assyrer heute zamieszcza list do ajatollaha Chomejniego autorstwa reprezentantów asyryjskiej opozycji na obczyźnie ${ }^{26}$. Jest on istotny z dwóch powodów. Po pierwsze ukazuje Asyryjczyków (zwłaszcza o poglądach lewicowych) nękanych i prześladowanych przez przedrewolucyjny reżim szacha, a zatem, pośrednio, zaangażowanie tej grupy na rzecz irańskiej rewolucji. Po drugie zaś dowodzi aktów prześladowań podejmowanych przez komitety rewolucyjne. Innym wydarzeniem wskazującym na umiędzynarodowienie

${ }^{24}$ H. Āszurijān, Āszurijān-e Irān, mellati ke bājad az nou szenācht, zamieszczony na stronie: http://assyrianstudies.org/ [dostęp: 10.06.2017].

25 J. Issaji, Tadżrobe āmuzande ast, „Margā” nr 23, 15 października 1982, s. 11.

26 Por. G. Yonan, Assyrer heute, s. 89. 
spraw Kościoła jest „kryzys zakładników” wywołany zajęciem amerykańskiej ambasady w Iranie w listopadzie 1979 roku przez irańskich rewolucjonistów. Arcybiskup Issaji pojawia się w tym kontekście jako duszpasterz uwięzionych, możemy również przypuszczać, że również jako mediator ${ }^{27}$.

Nieco inaczej wyglądała sytuacja Kościoła w diecezji Urmia-Salmas, nie tak licznego jak w diecezji teherańskiej, pozostającej raczej na uboczu wydarzeń rewolucyjnych. Tuż przed rewolucją obserwujemy jednak działania na rzecz renowacji szkół, co faktycznie odpowiada również szerszym inicjatywom podejmowanym na rzecz poprawy jakości życia Asyryjczyków zamieszkujących ten region. Arcybiskup Szauriz zmarł po długiej chorobie w 1981 roku. Informował o tym czytelników pisma „Marga” Tomas Meram (został w 1984 roku biskupem), podkreślając jego zasługi dla rozwoju regionu ${ }^{28}$.

Rewolucja, ograniczając możliwości swobodnego działania Kościołów i wspólnot religijnych, określała nowe formy kontaktu i relacji z państwem, wymuszając jednocześnie konieczność określenia własnego miejsca w nowej muzułmańskiej rzeczywistości. W istocie - podobnie jak w okresie przedrewolucyjnym - działalność podejmowana przez Asyryjczyków miała charakter polityczny i religijny. Społeczności Kościoła Chaldejskiego, Asyryjskiego Kościoła Wschodu oraz asyryjskich protestantów reprezentował w parlamencie wybierany przez nie poseł. Wydaje się jednak, że właśnie w tym okresie wzrosła znacząco pozycja zwierzchników religijnych społeczności jako mediatorów, inicjatorów i w pewnym stopniu również wykonawców polityki religijnej państwa. Wzrasta też wykorzystanie języka perskiego jako medium komunikacyjnego.

\section{KOŚCIÓŁ CHALDEJSKI W POREWOLUCYJNYM IRANIE}

Analiza danych statystycznych publikowanych rokrocznie w „Annuario Pontificio" (zob. tab. 2) ukazuje stały spadek populacji wiernych

27 Wspomina go Bruce Laingen, pełniący wówczas obowiązki ambasadora ambasady amerykańskiej w Teheranie, por. B. Laingen, Yellow ribbon. The secret journal of Bruce Laingen, Washington - New York - London 1992, s. 249.

28 T. Meram, Dar gozaszte osqof-e azam Szamuil Szouriz, „Marga” nr 16, 15 sierpnia 1981, s. 15-16. 
Kościoła Chaldejskiego w Iranie, największy w okresie między 1980 a 1990 rokiem, co odpowiada zarówno rewolucji, jak również trwającej do 1988 roku wojnie z Irakiem.

Tabela 2. Stan liczebny chaldejskich diecezji w Teheranie i Urmii

\begin{tabular}{|c|c|c|c|c|c|c|c|}
\hline ????? & 1980 & 1990 & 1999 & 2001 & 2003 & 2009 & 2014 \\
\hline Teheran & 9000 & 5000 & 3500 & 3150 & 3000 & 2650 & 2500 \\
\hline Urmia & 2150 & 2000 & 1500 & 1500 & 1500 & 1350 & 1350 \\
\hline
\end{tabular}

Źródło: „Annuario Pontificio”, za lata: 1981, 1991, 2000, 2002, 2004, 2010, 2015.

Odpływ chrześcijan z Iranu widoczny był również w połowie lat dziewięćdziesiątych oraz po 2005 roku, gdy prezydentem Iranu został Mahmud Ahmadineżad. Iran opuszczali w zdecydowanej większości ludzie młodzi, ulegając presji rodzin, rodziców pamiętających czasy rewolucji oraz idąc za przykładem krewnych mieszkających już poza granicami Iranu. $\mathrm{W}$ istocie największym problemem chrześcijan w porewolucyjnym Iranie stała się i jest nią do dzisiaj „gorączka migracyjna”29. Sytuację taką dobrze ilustruje wypowiedź jednego ze świeckich pracowników parafii chaldejskiej w Teheranie: „Gdy wybuchła rewolucja, myślałem o emigracji, wielu Asyryjczyków wyjechało wtedy z Iranu. Teraz, gdybym mógł, pewnie opuściłbym Iran, ale mam dzieci, jedno studiuje, drugie rozpocznie studia. Może one wyjadą. Do Europy. W Europie nikt nie patrzy na to, kim jesteś, ale na to, co potrafisz. Tu jesteśmy mniejszością, nie jesteśmy większością" [1_M.A.].

Warto podkreślić ostatnie zdanie przywołanej wypowiedzi: ,jesteśmy mniejszością, nie jesteśmy większością" ( $m a \bar{a}$ aqalijat hastim, aksarijat nistim), które wydaje się kluczowe dla zrozumienia poczucia napiętnowania i obcości, jakie towarzyszą chrześcijanom. Przynależność do mniejszości staje się stygmatem, owszem - daje pewne prawa, ogranicza jednak pełną partycypację w życiu politycznym czy kulturowym. Stąd również idealizowanie Europy jako przestrzeni wolności. Wypowiedzi, podobne do przywołanej, nie należą do rzadkości.

${ }^{29}$ Określenia tego używam za artykułem opublikowanym na stronie Oasis International Foundation, pt. Christians in Iran. A brief description, http://www.oasiscenter.eu/articles/christians-in-the-muslim-world/2015/06/11/christians-in-iran [dostęp: 10.06.2017]. 
W kontekście rozważań nad kategoryzacją mniejszości dwa aspekty wydają się niezwykle istotne: reprezentacja polityczna oraz irański dyskurs tożsamościowy, włączający lub wyłączający chrześcijan. Są one ze sobą związane. Konstytucja daje Asyryjczykom prawo do posiadania reprezentanta w parlamencie. W praktyce, mimo że ma bardziej charakter symboliczny, oznacza rzeczywiste działania na rzecz społeczności i nakłada na deputowanych obowiązek kontaktowania się ze zwierzchnikami Kościołów. Po rewolucji Asyryjczyków reprezentowali: Sargon Bajt-Uszana (niepełna kadencja), Atur Chnaniszu (dwie kadencje 1984-1992), Szamszun Maqsud-Pur (dwie kadencje 1992-2000) i od 2000 roku do chwili obecnej Jonatan Bet-Kolia, który jest również sekretarzem generalnym The Assyrian Universal Alliance. Z inicjatywy Bet-Kolii od 1993 roku ukazuje się pismo „Pajām-e Āšurijān”. Wydaje on również w niewielkim nakładzie inne pismo „Nedā-je haqiqat”, stanowiące raczej formę kontaktu z wyborcami i jego relacje z działalności parlamentarnej i pozaparlamentarnej.

Tematy poruszane na łamach „Pajām-e Āšurijān” doskonale korespondują ze zmianami zachodzącymi w kraju ${ }^{30}$. W ostatnich latach pojawia się na łamach pisma więcej informacji o „chrześcijańskich męczennikach” z czasów wojny z Irakiem. Wojna ma kluczowe znaczenie dla zrozumienia koncepcji męczeństwa (szahadat) wykorzystywanego instrumentalnie przez władzę i rozumianego jako ofiarność wobec państwa, tym samym odnoszonego również do chrześcijan i przez nich samych zaakceptowanego. Jest to jeden z elementów, które włączają mniejszości w Iranie w oficjalny dyskurs historyczny i tożsamościowy. Doskonałym przykładem takich działań jest muzeum poświęcone wojnie, działające w Teheranie, które nosi nazwę Muzeum Świętej Obrony (Muze-je Defä-e Moqaddas ${ }^{31}$ ). Można w niej znaleźć niewielką ekspozycję poświęconą mniejszościom religijnym z zamieszczonymi danymi dotyczącymi poległych w czasie wojny z Irakiem chrześcijan, żydów i zaratusztrian. Kultura męczeństwa (farhang-e szahadat), jak bywa określana kultura rewolucyjnego Iranu, ma charakter totalny, wpływając również na chrześcijan. Bezpośrednim

${ }^{30}$ Szerzej: M. Rzepka, Payām-e Āšuriyān - the Assyro-Chaldean publications in the Persian language in post-revolutionary Iran, „Orientalia Christiana Cracoviensia”, 2, 2010, s. 93--99.

31 Więcej informacji o muzeum na stronie internetowej: http://iranhdm.ir/ [dostęp 10.06.2017]. 
jednak powodem zamieszczania w piśmie informacji o Asyryjczykach, którzy zginęli w czasie wojny, była publikacja książki ajatollaha Chameneiego Masih dar szab-e qadr („Chrystus w nocy chwały”), będącej zapisem rozmów i dokumentacją wizyt Chameneiego, wówczas jako prezydenta Iranu, u rodzin, które straciły swoich bliskich w czasie wojny.

Wojna iracko-irańska oraz męczeństwo stanowią zatem istotny czynnik włączający chrześcijan w irańską wspólnotę doświadczeń, dokonując zrównania kategorii męczeństwa z patriotyzmem i ofiarnością wobec państwa. Równolegle z procesem włączania zachodzi jednak proces odwrotny: wyłączania, wykluczania i tworzenia granicy między Irańczykami-muzułmanami a reprezentantami mniejszości. W przypadku chrześcijan najbardziej wymiernym przykładem są regulacje dotyczące użycia języka perskiego.

Po śmierci arcybiskupa Issaji w 1999 roku, gdy arcybiskupem diecezji teherańskiej został Ramzi Garmo, pochodzący z Zakho w Iraku, nasiliła się tendencja do wydawania publikacji w języku perskim. Był to czas prezydentury Chatamiego, który podkreślał znaczenie dialogu międzyreligijnego, a tym samym również stosunkowo dobry okres w porewolucyjnej historii chrześcijan w Iranie. Garmo sugerował użycie języka perskiego przez chrześcijan w Iranie. Nie miał bynajmniej na myśli konwertytów - Irańczyków. Język perski miał być czynnikiem integrującym z kulturą Iranu, medium, przez które chrześcijanie mogli dawać świadectwo swojej obecności w tym kraju. Wspomniany wcześniej chaldejski Instytut św. Jana promował właśnie taką wizję języka perskiego jako chrześcijańskiego medium komunikacyjnego, upowszechniając treści chrześcijańskich w języku perskim poprzez tłumaczenia i wydawanie książek poświęconych historii Kościoła, dokumentów Soboru Watykańskiego II, modlitewników i fragmentów Pisma Świętego. Zachowanie własnego języka stanowiło zatem element tożsamości narodowej, a użycie języka perskiego manifestację uniwersalnego wymiaru chrześcijaństwa, oczywiście w obrębie Iranu, w którym faktycznie język perski stawał się sposobem międzykonfesyjnej i międzykościelnej komunikacji.

Projekty użycia języka perskiego w liturgii chaldejskiej były jednak bardzo różnie oceniane przez wiernych oraz członków Kościołów w Iranie. Niektóre krytyczne: „Biskup Ramzi pochodzi z Iraku i mówi innym dialektem niż my w Iranie. Ludzie czasem go nie rozumieją. Kiedy kiedyś 
przygotowano drogę krzyżową w języku perskim, przyszli do niego wierni i zapytali, czy chce z nich zrobić muzułmanów" [2_J.K.]. Przytoczona wypowiedź nie oznacza jednak krytyki działań arcybiskupa, raczej ukazuje trudną sytuację chrześcijan po 2005 roku, gdy wybór modlitwy w języku perskim stanowił manifestację poglądów o uniwersalnym, a także misyjnym charakterze Kościoła. Tak faktycznie irańska władza zaczęła rozumieć użycie języka perskiego w kościołach w Iranie. W 2010 roku zamknięty został Instytut św. Jana, publikacje w języku perskim skonfiskowane, a ksiądz Pierre Humblot wydalony z Iranu ${ }^{32}$. Ograniczenia dotyczące używania języka perskiego dotknęły w tym czasie również inne Kościoły.

Podsumowując, możemy stwierdzić, że w przypadku Kościoła Chaldejskiego w Iranie nie obserwujemy po rewolucji drastycznych działań podejmowanych przez państwo, a zmierzających do zamykania kościołów czy niszczenia mienia (wyjątkiem jest tu jednak Instytut św. Jana). Obserwujemy natomiast silną presję kulturową.

Tabela 2 przedstawia spadek liczby wiernych pomiędzy rokiem 2003 a 2009. Okres ten faktycznie odpowiada „trzeciej fali” migracyjnej od czasów rewolucji irańskiej w 1979 roku. Przypada ona na czas prezydentury Mahmuda Ahmadineżada (2005-2013). Ukazuje on dominujący stosunek władz względem chrześcijan w Iranie. Ich akceptację w wymiarze społecznym i kulturowym, ale jako elementu trwale obcego, wyalienowanego z przestrzeni języka perskiego. Zakrawa to na paradoks, zważywszy na postępujący proces przechodzenia na język perski obserwowany wśród młodych członków Kościoła Chaldejskiego.

Państwo wyznacza chrześcijanom możliwość partycypacji w przemianach państwowych, ale w sposób symboliczny, poprzez podkreślenie ofiarności w wojnie irańsko-irackiej - męczeństwa. Tak rozumiane męczeństwo nie jest jedynie elementem włączającym chrześcijan w historię Islamskiej Republiki Iranu, ale raczej próbą narzucenia wartości kulturowych mniejszościom oraz sposobów, w jakie mogą interpretować własną obecność w Iranie. W przypadku Kościoła Chaldejskiego obecność ta jest już jednak tylko symboliczna.

${ }^{32}$ L. Balbont, Zakazany język, w: Czarna księga prześladowań chrześcijan w świecie, red. J.-M. di Falco, T. Radcliffe, A. Riccardi, tłum. B. Baran, J. Gorecka-Kalita, M. Szewc-Osiecka, Poznań 2015, s. 303-310. 
Wyraźna zmiana charakteru irańskiego chrześcijaństwa powodowana migracjami oraz konwersjami religijnymi jest dziś szeroko dyskutowana i pojawia się oczywiście jako postulat badawczy, podejmowany również przez księży Kościoła Chaldejskiego w Iranie. Zdaniem jednego z duchownych: ,jedynie dwa typy chrześcijaństwa przetrwają w Iranie: irańskie chrześcijaństwo rozwijające się w nieformalnych kościołach domowych (kelisāhā-je chāne-i) oraz Kościół katolicki (łaciński) - jest potrzebny pracownikom ambasad" [2_J.K.]. Jest to niewątpliwie smutne podsumowanie procesów rozpoczętych rewolucją, które prowadzą do stopniowego zmniejszania się liczebności wiernych Kościoła Chaldejskiego w Iranie.

Streszczenie. Artykuł, koncentrując się na zmianach ilościowych, jakie zaszły wśród wiernych należących do Katolickiego Kościoła Chaldejskiego po rewolucji irańskiej w 1979 roku, stara się ukazać szerszy kontekst obecności chrześcijan w Islamskiej Republice Iranu. Przedstawia zatem sytuację społeczno-kulturową chrześcijan należących do Kościoła Chaldejskiego przed rewolucją, zwłaszcza zaś działalność społeczną i kulturową, akcentuje zmiany, jakie przyniosła rewolucja w postrzeganiu chrześcijan oraz możliwościach prowadzenia działalności religijnej i politycznej, a także obecną kondycję Kościoła, notującego stały i systematyczny odpływ wiernych, wywołany migracjami.

Słowa kluczowe: Katolicki Kościół Chaldejski; chrześcijanie; Asyryjczycy; Islamska Republika Iranu; rewolucja; islam.

Abstract. Disappearing Community. The Catholic Chaldean Church in Iran after the Iranian Revolution of 1979. By focusing on the quantitative changes that occurred among the members of the Catholic Chaldean Church after the Iranian Revolution of 1979, the article tries to depict a broader context of the Christian presence in the Islamic Republic of Iran. It presents the socio-cultural situation of the Christians belonging to the Chaldean Church before the revolution, underling their social and cultural activity, highlights the changes introduced by the revolution both in the attitudes toward the Christians and the opportunities given them to continue religious and political initiatives and, finally, it shows the present condition of the Church experiencing the decline of the Church members caused by migrations.

Key words: Catholic Chaldean Church; Christians; Assyrians; Islamic Republic of Iran; revolution; Islam. 


\section{BIBLIOGRAFIA}

„Annuario Pontificio", Città del Vaticano 1981, 1991, 2000, 2002, 2004, 2010, 2015.

Āszurijān, H., Āszurijān-e Irān, mellati ke bājad az nou szenācht, http://assyrianstudies. org/.

Backer, A.H., Revival and awakening. American evangelical missionaries in Iran and the origins of Assyrian nationalism, Chicago-London 2015.

Bajt-Mansur, W., Namunehā-ji az āsār-e bāstāni-je Āszurihā-je Irān, Tehrān 1377 (=1998).

Balbont, L., Zakazany język, w: Czarna księga prześladowań chrześcijan w świecie, red. J.-M. di Falco, T. Radcliffe, A. Riccardi, tłum. B. Baran, J. Gorecka-Kalita, M. Szewc-Osiecka, Poznań 2015, s. 303-310.

Barry, J., 'This is not Our Country': Declining Diversity in the Islamic Republic of Iran, „The Muslim World” 105 (2015) 3, s. 281-298.

Bradley, M., Too Many to Jail. The Story of Iran's New Christians, Oxford - Grand Rapids 2014.

Christians in Iran. A brief description, http://www.oasiscenter.eu/articles/christians-in-the-muslim-world/2015/06/11/christians-in-iran [dostęp: 10.06.2017].

Ettelāāti czand dar bāre-je Āszurihā, Markaz-e pażuheszhā-je Dżomhuri-je Eslāmi 1377 (=1998).

Healey, J., 'The church across the border': The Church of East and its Chaldean branch, w: Easter Christianity in the Modern Middle East, red. A. O’Mahony, E. Loosley, London - New York 2010, s. 41-55.

Heretics. Iran's Religious Minorities, Small Media 2014, https://smallmedia.org.uk/work/ heretics-irans-religious-minorities [dostęp: 10.06.2017].

Issaji, J., Tadżrobe āmuzande ast, „Margā” nr 23, 15 października 1982, s. 11.

Laingen, B., Yellow ribbon. The secret journal of Bruce Laingen, Washington - New York - London 1992.

Macuch, R., Assyrians in Iran, i. The Assyrian community (Āšūrīān) in Iran, w: Encyclopaedia Iranica, II/8, s. 817-822.

Meram, T., Dar gozaszte osqof-e azam Szamuil Szouriz, „Marga” nr 16, 15 sierpnia 1981, s. $15-16$.

Naby, E., The Assyrians of Iran: Reunification of a Millat 1906-1914, „International Journal of Middle East Studies" 8 (1977) 2, s. 237-249.

Persya. Rzut oka na dzieje misyi. Wymordowanie 4000 chrześcijan i arcybiskupa Sontaga $w$ Urmii, „Misye katolickie”, r. 38 (styczeń-luty), 1919, s. 58-59.

Prorok, C. V., Hemmasi, M., Demographic Changes in Iran's Officially Recognized Religious Minority Populations Since the Islamic Revolution, „African and Asian Studies” 1 (2002) 2, s. 63-86.

Rzepka, M., Payām-e Āšuriyān - the Assyro-Chaldean publications in the Persian language in post-revolutionary Iran, „Orientalia Christiana Cracoviensia” 2 (2010), s. 93-99. 
Rzepka, M., New Christians in the Islamic Republic of Iran: Regional and Global Implication, Shifting Identities: Changes in the Social, Political, and Religious Structures in the Middle East, red. M. Raheb, Diyar Publisher 2016, s. 183-194.

Sanasarian, E., Religious Minorities in Iran, Cambridge 2000.

Wilmshurst, D., The Ecclesiastical Organisation of the Church of the East 1318-1913, Louvain 2000.

Wilmshurst, D., The Martyred Church. A history of the Church of the East, London 2011.

Woźniak, M., Wspótcześni Asyryjczycy i Aramejczycy. Bliskowschodni chrześcijanie w poszukiwaniu tożsamości narodowej, Łódź 2014.

Yonan, G., Assyrer heute: Kultur, Sprache, Nationalbewegung der aramäisch sprechenden Christen im Nahen Osten; Verfolgung und Exil, Wien-Hamburg 1978. 